\title{
Association between patients' beliefs and oral antidiabetic medication adherence in a Chinese type 2 diabetic population [Corrigendum]
}

Wu P, Liu N. Patient Prefer Adherence. 2016;10:1161-1167.

On page 1163, Table 1, the copyright statement "Use of the MMAS- 8 is protected by US copyright laws. A license agreement to use the scale is available from: Donald E. Morisky, $\mathrm{ScD}$, ScM, MSPH, Professor, Department of Community Health Sciences, UCLA School of Public Health, 650 Charles E. Young Drive South, Los Angeles, CA 90095-1772, dmorisky@gmail.com" was not included in the Note section.

On page 1166, Acknowledgment section, the acknowledgment was "The authors thank the staff at the Department of Endocrinology, the First People's Hospital of Changzhou, for their assistance and cooperation with the studies. We thank Doctor Honghong Yao, Department of Pharmacology, Medical School of Southeast University, Nanjing, Jiangsu, People's Republic of China, for her assistance." however it should have been "The authors thank the staff at the Department of Endocrinology, the First People's Hospital of Changzhou, for their assistance and cooperation with the studies. We thank Doctor Honghong Yao, Department of Pharmacology, Medical School of Southeast University, Nanjing, Jiangsu, People's Republic of China, for her assistance. The authors thank Professor Donald E. Morisky, Department of Community Health Sciences, UCLA Fielding School of Public Health, Los Angeles, United States, for granting them to use the copyrighted MMAS-8.
Professor Donald E. Morisky has worked his entire career in developing the very important instrument for medicationtaking behavior measure. Permission to use the MMAS scales is required. ${ }^{33-35}$ Reproduction and distribution of the MMAS is protected by US copyright laws. A license agreement to use the scale is available from: Donald E. Morisky, $\mathrm{ScD}$, $\mathrm{ScM}$, MSPH, Professor, Department of Community Health Sciences, UCLA School of Public Health, 650 Charles E. Young Drive South, Los Angeles, CA 90095-1772, dmorisky@gmail.com."

On page 1167, References, these references were not included:

33. Morisky DE, Ang A, Krousel-Wood M, Ward H. Predictive Validity of a Medication Adherence Measure for Hypertension Control. Journal of Clinical Hypertension. 2008;10(5):348-354.

34. Krousel-Wood MA, Islam T, Webber LS, Re RS, Morisky DE, Muntner P. New Medication Adherence Scale Versus Pharmacy Fill Rates in Seniors with Hypertension. Am J Manag Care. 2009;15(1):59-66.

35. Morisky DE, DiMatteo MR. Improving the measurement of self-reported medication nonadherence: Final response. J Clin Epidemio. 2011;64(3):258-263.
Patient Preference and Adherence

\section{Publish your work in this journal}

Patient Preference and Adherence is an international, peer-reviewed, open access journal that focuses on the growing importance of patient preference and adherence throughout the therapeutic continuum. Patient satisfaction, acceptability, quality of life, compliance, persistence and their role in developing new therapeutic modalities and compounds to optimize

\section{Dovepress}

clinical outcomes for existing disease states are major areas of interest for the journal. This journal has been accepted for indexing on PubMed Central. The manuscript management system is completely online and includes a very quick and fair peer-review system, which is all easy to use. Visit http://www. dovepress.com/testimonials.php to read real quotes from published authors. 